\title{
Effect of Plant Species on the Performance and Bacteria Density Profile in Vertical Flow Constructed Wetlands for Domestic Wastewater Treatment in a Tropical Climate
}

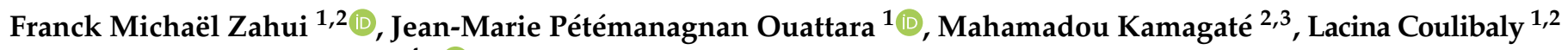 \\ and Alexandros I. Stefanakis $4, *$ (i) \\ 1 Laboratory of Environment and Aquatic Biology, Department of Sciences and Environment Management, \\ Nangui Abrogoua University, 02 BP 801 Abidjan 02, Côte d'Ivoire; michael.zahui@univ-man.edu.ci (F.M.Z.) \\ jm_petemanagnan@yahoo.fr (J.-M.P.O.); coulacina2003@yahoo.fr (L.C.) \\ 2 Department of Agronomic, Forestry and Environmental Engineering, University of Man, \\ BP 20 Man, Côte d'Ivoire; kamagate.mahamadou@ensc-rennes.fr \\ 3 Graduate National School of Chemistry of Rennes, UMR CNRS 6226, 11 Allée Beaulieu, CEDEX 7, \\ 35708 Rennes, France \\ 4 Laboratory of Environmental Engineering \& Management, School of Chemical and Environmental \\ Engineering, Technical University of Crete, 73100 Chania, Greece \\ * Correspondence: astefanakis@enveng.tuc.gr
}

check for updates

Citation: Zahui, F.M.; Ouattara, J.-M.P. Kamagaté, M.; Coulibaly, L.; Stefanakis, A.I. Effect of Plant Species on the Performance and Bacteria Denstity Profile in Vertical Flow Constructed Wetlands for Domestic Wastewater Treatment in a Tropical Climate. Water 2021, 13, 3485. https://doi.org/10.3390/w13243485

Academic Editor: Abasiofiok Mark Ibekwe

Received: 3 October 2021

Accepted: 1 December 2021

Published: 7 December 2021

Publisher's Note: MDPI stays neutral with regard to jurisdictional claims in published maps and institutional affiliations.

Copyright: (C) 2021 by the authors Licensee MDPI, Basel, Switzerland. This article is an open access article distributed under the terms and conditions of the Creative Commons Attribution (CC BY) license (https:// creativecommons.org/licenses/by/ $4.0 /)$

\begin{abstract}
Bacteria are frequently studied due to their involvement in pollutants transformation processes during wastewater treatment. In this study, the treatment efficiency, bacteria densities and their vertical profile were investigated in pilot-scale vertical flow constructed wetlands (VFCW) planted with different plant species under a tropical climate in west Africa. Five beds were planted with local plant species, i.e., Andropogon gayanus, Chrysopogon zizanioides, Echinochloa pyramidalis, Pennisetum purpureum and Tripsacum laxum, while one bed remained unplanted. These species have been rarely used in CWs while some (e.g., T. laxum) are tested for the first time. After a 7-month trial, bacteria densities were measured in substrate samples separated into six layers along the bed depth. Plants presence enhanced the bacterial density and VFCW efficiency; the removal rates of organic matter (90.9-95.9\%; COD and 95.2-98.5\%; BOD $)$, nitrogen (74.3-84\%; TN and 76-84\%; $\mathrm{NH}_{4}-\mathrm{N}$ ) and phosphorus (77.4-96.9\%; $\mathrm{PO}_{4}-\mathrm{P}$ ) were higher by $5.9-24.1 \%$ compared to the control bed, providing an overall excellent treatment performance for a single-stage VFCW system. Small numbers of anaerobic bacteria were obtained in the VFCWs, explaining the low-to-zero $\mathrm{NO}_{3}-\mathrm{N}$ removal, except for the VFCWs with T. laxum and P. purpureum. Aerobic bacteria decreased from the upper to bottom layers from 17.4 to $0.1 \times 10^{6} \mathrm{CFU} / \mathrm{g}$ in the planted beds, while anaerobic bacteria increased from 0.1 to $2.1 \times 10^{6} \mathrm{CFU} / \mathrm{g}$. Anaerobic bacteria were more abundant in the unplanted than in the planted beds. The total bacteria count was dominated by aerobic bacteria, and decreased from the surface towards the bottom. Overall, the VFCW with P. purpureum demonstrated the highest efficiency, indicating that this design is an effective and sustainable nature-based solution for wastewater treatment in a tropical climate.
\end{abstract}

Keywords: constructed wetlands; vertical flow; domestic wastewater; plant species; bacterial density; aerobic bacteria; anaerobic bacteria; tropical climate; nature-based solutions

\section{Introduction}

Constructed wetlands (CWs) are engineered systems, designed and constructed to use the natural functions of wetland vegetation, soil, gravel, and the associated microbial populations to treat and purify wastewater [1-3]. This sustainable technology typically requires small amounts of energy and represents a nature-based solution for water and wastewater management [4]. CWs generally have low investment and, especially, operating costs, are easy to operate, and can be easily integrated in the landscape $[3,5]$. Their high 
treatment performance has allowed their application not only for municipal but also for various industrial effluents [6-9]. Integrating the implementation of nature-based solutions with treated effluent reuse and recycling [10-12] is nowadays viewed as circular water management concept $[13,14]$.

CWs are usually classified according to the water flow patterns, i.e., horizontal and vertical [2]. In the horizontal flow systems, dissolved oxygen concentration is limited [15], while vertical flow CWs (VFCWs) are typically unsaturated and operate under a predominantly aerobic regime $[2,16]$. Moreover, the use of subsurface CWs reduces the environmental risks, such as the release of odors and gases and the proliferation of mosquitoes [5]. The VFCW design increases the oxygen transfer rate, improves the nitrification process, and promotes the oxidation capacity of organic matter $[2,17,18]$.

Unlike most treatment processes that focus on a single treatment mechanism or pollutant type, CWs use several synergetic processes to simultaneously transform and/or remove pollutants. There are physical, chemical and biological processes, such as sedimentation, precipitation, adsorption, plant uptake, and biological metabolism by microorganisms [2,19-21]. These mechanisms are related to the main components of the system, namely plants, substrate and microorganisms living in the substrate (soil, gravel, or sand; [22]). Biological processes mediated by the various microorganisms are believed to play a key role in pollutants removal in CWs $[2,19]$. In particular, microbial processes are considered the main pollutant removal mechanism of organic matter and nitrogen [16,23-26]. Microorganisms develop naturally in the bed matrix, and mainly depend on the hydraulic conditions, wastewater characteristics, substrate characteristics, nutrient quality and availability, plants, and environmental factors, such as oxygen level, pH and temperature [22,27]. Microorganisms that live in CWs include bacteria, algae, fungi, protozoa, zooplankton, viruses and nematodes [28,29]. However, the most frequently reported studies focus on bacteria, due to their effective involvement in removal processes [27,29]. Different types of bacteria species can decompose, transform or assimilate wastewater pollutants under aerobic or anaerobic conditions in CWs substrate.

Despite the widespread use of CW technology around the world, the number of published studies is still relatively small under tropical climates, where also most of the developing countries are found [7,30-33]. However, the warmer climate of these regions may have a positive effect on the design and the performance of these systems, since the biological processes are favored and enhanced under higher temperatures [2,5,34]. This means that CWs, as a sustainable and cost-effective technology, offer particular economic and technical advantages to low income regions. In addition, the vertical distribution of bacterial flora as a function of different depths within CWs has not been thoroughly investigated to date, especially for plant species found under tropical climates. The vertical profile of these bacteria could assist in assessing the CW performance, and provide new insight to better understand the various transformation and pollutant removal mechanisms that take place in the system. Therefore, the aim of this study was to examine the efficiency of pilot-scale VFCWs planted with different native plant species that are rarely used so far in CW systems (i.e., Andropogon gayanus, Chrysopogon zizanioides, Echinochloa pyramidalis, Pennisetum purpureum and Tripsacum laxum) in monoculture, and investigate the aerobic, anaerobic and total bacteria densities and their vertical distribution profile under a tropical climate. More specifically, the objectives of this study were to determine the VFCWs removal efficiency and associate these results with the densities of aerobic, anaerobic and total bacteria from the upper to the bottom layers of the bed substrate.

\section{Materials and Methods}

\subsection{Domestic Wastewater Characteristics}

Synthetic domestic wastewater was used in this study to limit the fluctuation of pollutant concentrations in real wastewater during the trial [35-37]. The preparation and composition of the synthetic domestic wastewater were based on previously described methods $[38,39]$. However, some modifications were adopted in order to match the char- 
acteristics, i.e., nitrogen $(\mathrm{N})$, phosphorus $(\mathrm{P})$ and carbon $(\mathrm{C})$ concentrations, to domestic wastewater found in developing countries. The synthetic domestic wastewater used the following target composition: chemical oxygen demand (COD) $628 \mathrm{mg} / \mathrm{L}, 5$ day-biochemical oxygen demand $\left(\mathrm{BOD}_{5}\right) 380 \mathrm{mg} / \mathrm{L}$, total nitrogen $(\mathrm{TN}) 45 \mathrm{mg} / \mathrm{L}$, total suspended solids (TSS) $300 \mathrm{mg} / \mathrm{L}$, total phosphorus (TP) $12 \mathrm{mg} / \mathrm{L}$ and $\mathrm{pH}=6.7-8$. All chemicals used for the wastewater preparation were purchased from Sigma Aldrich (France), having high purity analytical properties. The chemicals and their concentrations used are shown in Table 1.

Table 1. Chemicals used to prepare the synthetic domestic wastewater composition.

\begin{tabular}{cc}
\hline Chemical & Concentration $(\mathbf{m g} / \mathbf{g})$ \\
\hline Glucose & 200 \\
Starch & 200 \\
Yeast & 40 \\
Milk powder & 120 \\
Urea & 30 \\
$\mathrm{NH}_{4} \mathrm{Cl}$ & 70 \\
$\mathrm{KH}_{2} \mathrm{PO}_{4}$ & 80 \\
$\mathrm{NaHCO}_{3}$ & 200 \\
$\mathrm{MgSO}_{4} ; 7 \mathrm{H}_{2} \mathrm{O}$ & 50 \\
$\mathrm{FeSO}_{4} ; 7 \mathrm{H}_{2} \mathrm{O}$ & 2 \\
$\mathrm{MnSO}_{4} ; \mathrm{H}_{2} \mathrm{O}$ & 2 \\
$\mathrm{CaCl}_{2} ; 6 \mathrm{H}_{2} \mathrm{O}$ & 3 \\
$\mathrm{Bentonite}$ & 60 \\
\hline
\end{tabular}

\subsection{Experimental Setup}

The study was carried out over a 7-month period, i.e., from February to August 2017 at the Nangui Abrogoua University, Abidjan, Côte d'Ivoire. This area is characterized by a humid tropical climate with an average annual temperature around $25^{\circ} \mathrm{C}$.

Six pilot VFCW concrete beds were built with a rectangular-shaped surface $\left(1.45 \mathrm{~m}^{2}\right)$ and dimensions $1.45 \mathrm{~m}$ length, $1.0 \mathrm{~m}$ width and $0.60 \mathrm{~m}$ depth (Figure 1), as already described $[35,36]$. The beds were filled from bottom to the top with a $10 \mathrm{~cm}$ gravel layer $(5 / 15 \mathrm{~mm})$ covered with geotextile cloth and a $60 \mathrm{~cm}$ white lagoon sand layer (mean sand diameter $=0.572 \mathrm{~mm}$, uniformity coefficient $=0.4$, porosity $=37.5 \%$ ), previously washed to remove clay, loam, and organic matter. Each bed was equipped with a wastewater feeding network consisting of six PVC pipes (length: $1.45 \mathrm{~m}$; diameter; $0.008 \mathrm{~m}$ ) with 60 lateral holes (Figure 1), to allow for uniform distribution of the inflow across the surface. The bottom bed slope was $1 \%$ to facilitate the treated water collection via a PVC pipe ( $0.032 \mathrm{~m}$ diameter) that drained out the treated effluent, which was gravitationally collected in effluent tanks (100 L volume). All beds were independent to each other and operated in parallel.

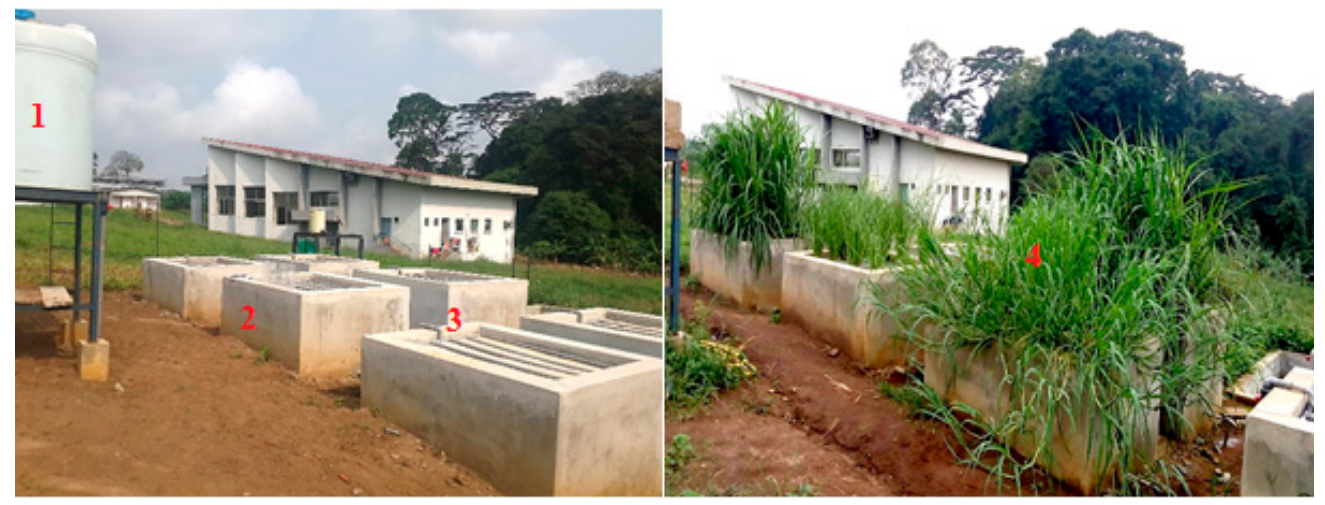

Figure 1. The experimental setup of the study; (1) feeding tank, (2) pilot VFCW beds, (3) inlet feeding pipes, (4) plant growth in the pilot beds two months after planting. 


\subsection{Plant Species}

Five out of the six pilot VFCWs beds were planted with different native plant species collected from different regions of Côte d'Ivoire including Andropogon gayanus, Chrysopogon zizanioides, Echinochloa pyramidalis (Lam.), Pennisetum purpureum and Tripsacum laxum. These plant species were selected due to the economic interest of their biomass and are highly appreciated by agro-pastoralists. In addition to having a positive impact on wastewater treatment, they could generate further revenue that can support the maintenance costs. For example, P. purpureum is a valuable fodder grass with high nutrient uptake and biomass yield [40]. A. gayanus is also a common perennial forage grass of the tropical regions that forms tall and dense stands and has a high evapotranspiration capacity [40-42]. C. zizanioides is a high biomass perennial tropical grass that has been successfully used for soil and water conservation due to its robust root system and tolerance for adverse environmental conditions [43,44], and it is grown worldwide for perfumery, agriculture, and bioengineering $[45,46]$. E. pyramidalis produces a high shoots density and a dense mat of roots and rhizomes, allowing a high evapotranspiration rate, and has been successfully used for wastewater treatment and fecal sludge dewatering $[47,48]$. T. laxum is also widely used for its fodder value in many countries as a major feed source for dairy cattle [49], but has not yet been tested in CWs for wastewater treatment.

\subsection{Operation}

Five pilot VFCWs beds were planted with plant seedlings (i.e., 9 plants $/ \mathrm{m}^{2}$ ) at a spacing of $40 \mathrm{~cm} \times 40 \mathrm{~cm}$ in monoculture, while the sixth bed remained an unplanted control. The young plants were collected from nurseries established near the experimental area having an aboveground height of $20 \mathrm{~cm}$. After planting, the beds were fed with tap water for one month to allow for plants acclimatization. After the acclimation period, each bed was intermittently fed ( 3 days/week) with $80 \mathrm{~L}$ synthetic domestic wastewater at a hydraulic load of $0.055 \mathrm{~m} / \mathrm{d}$ for over 6 months.

\subsection{Water Sampling}

During the experimental period, wastewater samples from the influent and all effluents were collected on a weekly basis and stored in ethylene bottles at $4{ }^{\circ} \mathrm{C}$ for analysis. In total, 24 samples were taken from each bed during the trial. The growth response of the tested plant species was determined from the stump diameter and the aboveground biomass [37]. The produced aboveground plant biomass was harvested and weighed at the end of each two-month growth cycle, and the plants stump diameters were measured.

\subsection{Substrate Sampling and Microbial Biomass Analysis}

For the bed microfauna study, sampling consisted of substrate collection at the end of the treatment trial. This was performed in six substrate layers across the vertical profile, ranging from the upper to the bottom layers of the beds, as follows: L1 [0-10 cm], L2 [10-20 cm], L3 [20-30 cm], L4 [30-40 cm], L5 [40-50 cm] and L6 [50-60 cm].

Substrate sampling for bacteria analysis was performed by collecting cores with a PVC pipe (diameters of $16 \mathrm{~mm}$ ). As already described [30], the surface of the beds was divided into three equal sections to get a better representation of the bacteria distribution within the beds. In each section, three sampling points (one at each extremity of the bed, and one at the center) were uniformly distributed over the width of the beds from which a composite sample of the substrate layer under consideration was formed. The collected samples were stored in jars at $2{ }^{\circ} \mathrm{C}$ for analysis.

An analysis of the bacteria was carried out according to the technique of germs inoculation in plate count agar (PCA) [50]. About $5 \mathrm{~g}$ of the substrate sample were suspended in a sterile saline solution $(0.85 \% \mathrm{NaCl})$ of $50 \mathrm{~mL}$ and inoculated in triplicate onto PCA after stirring and sedimentation at room temperature. The aerobic germs were grown in a single layer of agar, whereas the anaerobic germs were within a double layer of agar. These germs were incubated at $37^{\circ} \mathrm{C}$ for $48 \mathrm{~h}$, and then the number of colonies formed were counted 
according to the international standard ISO 6222 [51]. The total number of bacteria in each sample was determined by adding the numbers of aerobic and anaerobic bacteria.

\subsection{Analytical Methods}

Different methods were used to analyze the parameters in three duplications: $\mathrm{pH}$ and dissolved oxygen (DO) were determined according to ISO 10523 [52] and ISO 5814 [53], respectively. $\mathrm{COD}, \mathrm{BOD}_{5}, \mathrm{TN}$, ammonium $\left(\mathrm{NH}_{4}-\mathrm{N}\right)$, nitrate $\left(\mathrm{NO}_{3}-\mathrm{N}\right)$ and orthophosphate $\left(\mathrm{PO}_{4}-\mathrm{P}\right)$ were also determined according to ISO 6060/2 [54], ISO 5815/1 [55], ISO 5663 [56], ISO 7150/1 [57], ISO 7890/3 [58] and ISO 6878 [59], respectively. All analyses were carried out at the Laboratory of Environment and Aquatic Biology of Nangui Abrogoua University and the National Laboratory for Quality Assurance Testing, Metrology and Analysis of Côte d'Ivoire.

\subsection{Statistical Analysis}

Statistical tests were performed using R Studio 3.3.2 software. The data were analyzed through the Kruskal-Wallis tests (also called one-way analysis of variance; ANOVA) at the $95 \%$ significance level $(p \leq 0.05)$ after Shapiro-Wilk normality test to compare the performance of the VFCW units in the removal of the various parameters. Post hoc pair comparisons were also performed to test equal variations, using Tukey's honestly significant difference test. Homogeneity of variance tests (Levene) were bypassed, since the number of data points for each group was the same.

\section{Results}

\subsection{Plant Growth Response}

The mean aboveground biomass and stump diameter of the plant species in the VFCWs are shown in Table 2. Overall, the aboveground biomass of the plants ranged from $1.8 \pm 0.7$ to $15.2 \pm 0.7 \mathrm{~kg} / \mathrm{m}^{2}$, while the stump diameters varied from $8.6 \pm 3.6$ to $21.3 \pm 9.5 \mathrm{~cm}$. The plant aboveground biomasses were classified in the following order $\left(\mathrm{kg} / \mathrm{m}^{2}\right)$ : P. purpureum $(15.2)>$ T. laxum $(13.1)>$ E. pyramidalis $(8.3)>$ A. gayanus (2.6) $>$ C. zizanioides (1.8). However, a Mann-Whitney test showed that the biomasses developed by E. pyramidalis, P. purpureum and T. laxum were significantly higher than those of A. gayanus and C. zizanioides $(p<0.05)$. On the other hand, regarding aboveground biomasses, the sequence of the mean values of diameter stumps was $(\mathrm{cm})$ : P. purpureum (21.3) $>$ T. laxum $(16.4)>$ E. pyramidalis (12.1) > C. zizanioides (10.7) $>$ A. gayanus (8.7). No significant differences were observed between the diameters of the different plant stumps $(p>0.05)$. Although the stump diameter of $C$. zizanioides was higher than that of A. gayanus, it developed the lowest aboveground biomass.

Table 2. Mean and standard deviation of plant aboveground biomass and stump diameter of the different plant species in the pilot VFCW beds. Values within the same column followed by the same superscript letter (i.e., a, b) are not statistically significantly different at $p<0.05$.

\begin{tabular}{ccc}
\hline Plant Species & Aboveground Biomass $\mathbf{( k g / \mathbf { m } ^ { 2 } )}$ & Stumps Diameter $\mathbf{( c m )}$ \\
\hline A. gayanus & $2.6^{\mathrm{a}} \pm 1.8$ & $8.6^{\mathrm{a}} \pm 3.6$ \\
C. zizanioides & $1.8^{\mathrm{a}} \pm 0.7$ & $10.7^{\mathrm{a}} \pm 4.2$ \\
E. pyramidalis & $8.3^{\mathrm{b}} \pm 4.6$ & $12.1^{\mathrm{a}} \pm 5.5$ \\
P. purpureum & $15.2^{\mathrm{b}} \pm 0.7$ & $21.3^{\mathrm{a}} \pm 9.5$ \\
T. laxum & $13.1^{\mathrm{b}} \pm 2.3$ & $16.4^{\mathrm{a}} \pm 6.7$ \\
\hline
\end{tabular}

\subsection{Wastewater Treatment Performance}

\subsubsection{Assessment of Physical Parameters}

The mean values of $\mathrm{pH}, \mathrm{DO}$ and water volume at the inlet and outlet of all beds are shown in Table 3. The effluent $\mathrm{pH}$ values were higher than those of the raw wastewater. The average effluent $\mathrm{pH}$ of the planted beds (between 6.92 and 7.17) was slightly lower than 
those of the unplanted bed (7.33). The sequence of $\mathrm{pH}$ mean values was in the following order: raw wastewater $(6.81)<$ A. gayanus $(6.92)<$ E. pyramidalis $(6.93)<$ C. zizanioides $(7.05)$ $<$ P. purpureum $(7.06)<$ T. laxum $(7.17)<$ unplanted (7.32) (Table 2). Significant differences were observed between the $\mathrm{pH}$ of raw wastewater and the effluent of the planted beds, as well as between the different planted beds (Mann-Whitney test: $p<0.05$ ).

Table 3. Mean and standard deviation of $\mathrm{pH}$, dissolved oxygen (DO) and water volume at the inlet and outlet of the pilot VFCW beds with different plant species. Values within the same column followed by the same superscript letter (i.e., a, b, $c$, $\mathrm{d}, \mathrm{e}, \mathrm{f})$ are not statistically significantly different at $p<0.05$.

\begin{tabular}{|c|c|c|c|c|c|c|c|}
\hline \multirow[b]{2}{*}{ Parameter } & \multirow[b]{2}{*}{ Inlet } & \multicolumn{6}{|c|}{ Outlet } \\
\hline & & $\begin{array}{c}T . \\
\text { laxum }\end{array}$ & $\begin{array}{c}A . \\
\text { gayanus }\end{array}$ & $\begin{array}{c}C . \\
\text { zizanioides }\end{array}$ & $\begin{array}{c}E . \\
\text { pyramidalis }\end{array}$ & $\begin{array}{c}P . \\
\text { purpureum }\end{array}$ & Unplanted \\
\hline $\mathrm{pH}$ & $6.81^{\mathrm{a}} \pm 0.1$ & $7.17^{\mathrm{cb}} \pm 0.3$ & $6.92^{a} \pm 0.3$ & $7.05^{c} \pm 0.3$ & $6.93^{a} \pm 0.3$ & $7.06^{c} \pm 0.2$ & $7.33^{b} \pm 0.3$ \\
\hline $\mathrm{DO}(\mathrm{mg} / \mathrm{L})$ & $2.13^{a} \pm 0.6$ & $7.53^{b} \pm 1.6$ & $6.50^{c} \pm 0.8$ & $6.70^{c} \pm 1$ & $6.63^{c} \pm 1$ & $7.24^{b} \pm 1.1$ & $5.41^{\mathrm{d}} \pm 0.9$ \\
\hline Volume (L) & $80^{a}$ & $55.6^{\mathrm{b}} \pm 3.8$ & $60.3^{c} \pm 3$ & $62.2^{\mathrm{d}} \pm 3.6$ & $58.6^{\mathrm{e}} \pm 5.8$ & $54.2^{b} \pm 4.3$ & $72.4^{\mathrm{f}} \pm 1.9$ \\
\hline
\end{tabular}

Effluent DO values (i.e., between $5.41 \pm 0.9$ and $7.53 \pm 1.6 \mathrm{mg} / \mathrm{L}$ ) were higher compared to the inlet (i.e., $2.13 \pm 0.6 \mathrm{mg} / \mathrm{L}$ ), whereas effluent values of the planted beds were higher than of the unplanted bed. Significant differences were found among the planted beds (Mann-Whitney test: $p<0.05$ ).

The water volume collected at the outlet of the beds was always smaller than the raw wastewater volume applied $(80 \mathrm{~L})$. The average effluent water volume in the unplanted bed $(72.4 \pm 1.9 \mathrm{~L})$ was the highest and then followed the beds planted with $C$. zizanioides $(62.2 \pm 3.6 \mathrm{~L})$, A. gayanus $(60.3 \pm 3 \mathrm{~L})$, E. pyramidalis $(58.6 \pm 5.8 \mathrm{~L})$, T. laxum $(55.6 \pm 3.8 \mathrm{~L})$ and P. purpureum (54.2 $\pm 4.3 \mathrm{~L}$ ). Significant differences were found between the unplanted bed and the planted beds for the effluent volumes $(p<0.05)$, while those of the beds planted with P. purpureum and T. laxum were similar and significantly lower than the effluent water volume of the other planted beds.

\subsubsection{Assessment of Chemical Parameters}

Table 4 shows the influent and effluent concentrations and removal efficiencies of the VFCWs for different parameters. During the experimental period, the influent concentrations in the synthetic wastewater varied from $535-623.3 \mathrm{mg} / \mathrm{L}$ (COD), 356.1-373.8 mg/L (BOD $)_{5}$, 37.6-44.5 mg/L (TN), 31-35 mg/L $\left(\mathrm{NH}_{4}-\mathrm{N}\right), 1.1-1.97 \mathrm{mg} / \mathrm{L}\left(\mathrm{NO}_{3}-\mathrm{N}\right)$ and $6.8-7.9 \mathrm{mg} / \mathrm{L}$ $\left(\mathrm{PO}_{4}-\mathrm{P}\right)$, with respective average values of $611.8 \mathrm{mg} / \mathrm{L}, 369.8 \mathrm{mg} / \mathrm{L}, 41.4 \mathrm{mg} / \mathrm{L}, 33.4 \mathrm{mg} / \mathrm{L}$, $1.8 \mathrm{mg} / \mathrm{L}$ and $7.4 \mathrm{mg} / \mathrm{L}$. The average removal efficiencies varied between $90.9-95.9 \%$ for COD, $95.2-98.5 \%$ for $\mathrm{BOD}_{5}, 74.3-84 \%$ for TN, $76-84 \%$ for $\mathrm{NH}_{4}-\mathrm{N}$, and $77.4-96.9 \%$ for $\mathrm{PO}_{4}-\mathrm{P}$ in the planted beds, while in the unplanted bed, the removal efficiency for all parameters varied from $53.3-89.3 \%$. The plant presence significantly enhanced the removals of all parameters by 5.9 up to $24.1 \%$ compared to the unplanted bed (Mann-Whitney test: $p<0.05)$. The removal efficiency in order of performance was: P. purpureum $>$ T. laxum $>$ E. pyramidalis $>$ A. gayanus $>$ C. zizanioides $>$ unplanted. Moreover, the pilot VFCWs with P. purpureum and T. laxum were significantly more efficient than the other planted beds (Kruskal-Wallis test, $p<0.05$ ).

\subsection{Bacteria Densities Measurements}

Aerobic and anaerobic bacteria densities were assessed in the VFCWs substrate (Figure 2). Overall, aerobic bacteria density was higher than that of anaerobic bacteria in all planted VFCWs beds, except for the unplanted bed. The median density of aerobic bacteria in the VFCWs (Figure 2A) was in the following order (expressed in $10^{6} \mathrm{CFU} / \mathrm{g}$ ): P. purpureum (7.7) $>$ T. laxum (6.4) $>$ E. pyramidalis (4.8) $>$ A. gayanus (4.5) $>$ C. zizanioides (2.4) $>$ unplanted (1.4). A significant difference was observed between the VFCW bed planted 
with C. zizanioides and the other beds (Mann-Whitney test: $p<0.05$ ), while no significant differences were found among the other planted beds.

Table 4. Average (aver), maximum ( $\max$ ), and minimum (min) concentrations (mg/L) and removals (\%) of different parameters in the inlet and the outlet of the pilot VFCWs with different plant species. Values within the same column followed by the same superscript letter (i.e., a, b, c, d, e, f) are not statistically significantly different at $p<0.05$.

\begin{tabular}{|c|c|c|c|c|c|c|c|c|c|c|c|c|c|}
\hline \multirow{2}{*}{ Bed } & & \multicolumn{2}{|c|}{ COD } & \multicolumn{2}{|c|}{ BOD $_{5}$} & \multicolumn{2}{|c|}{ TN } & \multicolumn{2}{|c|}{$\mathrm{NH}_{4}-\mathrm{N}$} & \multicolumn{2}{|c|}{$\mathrm{NO}_{3}-\mathrm{N}$} & \multicolumn{2}{|c|}{$\mathrm{PO}_{4}-\mathrm{P}$} \\
\hline & & $\mathrm{mg} / \mathrm{L}$ & $\%$ & $\mathrm{mg} / \mathrm{L}$ & $\%$ & $\mathrm{mg} / \mathrm{L}$ & $\%$ & $\mathrm{mg} / \mathrm{L}$ & $\%$ & $\mathrm{mg} / \mathrm{L}$ & $\%$ & $\mathrm{mg} / \mathrm{L}$ & $\%$ \\
\hline \multirow{3}{*}{ Inlet } & Aver & $611.8^{a}$ & - & $369.8^{a}$ & - & $41.4^{\mathrm{a}}$ & - & $33.4^{\mathrm{a}}$ & - & $1.8^{\mathrm{a}}$ & - & $7.4^{\mathrm{a}}$ & - \\
\hline & Max & 623.3 & - & 373.8 & - & 44.5 & - & 35 & - & 2 & - & 7.9 & - \\
\hline & Min & 535 & - & 356.1 & - & 37.6 & - & 31 & - & 1.1 & - & 6.8 & - \\
\hline \multirow{3}{*}{ T. laxum } & Aver & $48.7 b^{c}$ & $94.5^{\mathrm{a}}$ & $14.7^{\mathrm{b}}$ & $97.2^{a}$ & $11 b^{d}$ & $81.4^{\mathrm{ac}}$ & $9^{b c}$ & $81.3^{a}$ & $1.36^{\mathrm{a}}$ & $24.3^{a}$ & $0.6^{\mathrm{b}}$ & $94.6^{\mathrm{a}}$ \\
\hline & Max & 67 & 97.2 & 19.2 & 97.9 & 17.2 & 94.9 & 14 & 94.1 & 7.5 & 96.4 & 2 & 99.9 \\
\hline & Min & 27.3 & 92.5 & 11.5 & 95.8 & 3.3 & 69.2 & 2.4 & 77.2 & 0.1 & $\mathrm{n}$ & 0.01 & 81.7 \\
\hline \multirow{3}{*}{ A. gayanus } & Aver & $73.9 b^{c}$ & $90.9^{b}$ & $23.3^{c}$ & $95.2^{b}$ & $12.8^{\mathrm{bc}}$ & $76.3^{a b}$ & $9.6^{b c}$ & $78.2^{\mathrm{ab}}$ & $4.4^{\mathrm{b}}$ & $\mathrm{n}$ & $2^{c}$ & $79.9^{b}$ \\
\hline & Max & 121.4 & 93.8 & 30.7 & 96.7 & 20.1 & 94.6 & 15.3 & 94.8 & 12.7 & 38.2 & 4.1 & 95.3 \\
\hline & Min & 52.8 & 85.6 & 16.3 & 93.4 & 3.2 & 61 & 2.3 & 75.1 & 1.2 & $\mathrm{n}$ & 0.5 & 61 \\
\hline \multirow{3}{*}{ C. zizanioides } & Aver & $63.4^{\mathrm{b}}$ & $91.9^{c}$ & $21.8^{\mathrm{c}}$ & $95.4^{b}$ & $13.6^{c}$ & $74.3^{b}$ & $10.2^{c}$ & $76^{b}$ & $4.3^{\mathrm{b}}$ & $\mathrm{n}$ & $2.1^{c}$ & $77.4^{b}$ \\
\hline & Max & 75.8 & 93.7 & 30.7 & 97.5 & 20.7 & 88.5 & 17.3 & 91.2 & 9.4 & 85.4 & 3.6 & 86.3 \\
\hline & Min & 53.2 & 89.8 & 11.5 & 93 & 6.2 & 57.4 & 3.6 & 72.2 & 0.3 & $\mathrm{n}$ & 1.4 & 61.1 \\
\hline \multirow{3}{*}{ E. pyramidalis } & Aver & $55.3^{\mathrm{bc}}$ & $93.4^{\mathrm{d}}$ & $18.4^{\mathrm{d}}$ & $96.4^{c}$ & $13.3^{\mathrm{b}}$ & $76.1^{\mathrm{b}}$ & $9.8^{\mathrm{bc}}$ & $78.4^{\mathrm{ab}}$ & $4^{\mathrm{b}}$ & $\mathrm{n}$ & $1.7^{c}$ & $82.6^{\mathrm{b}}$ \\
\hline & Max & 64.2 & 95.2 & 24 & 98.4 & 23.5 & 93.3 & 18.6 & 94.4 & 11.8 & 94.8 & 4.1 & 99.6 \\
\hline & Min & 39.7 & 91.2 & 7.7 & 94.2 & 3.6 & 58.3 & 2.5 & 71.3 & 0.1 & $\mathrm{n}$ & 0.04 & 62.5 \\
\hline \multirow{3}{*}{ P. purpureum } & Aver & $36.7^{c}$ & $95.9^{\mathrm{e}}$ & $8.0^{\mathrm{e}}$ & $98.5^{d}$ & $9.6^{d}$ & $84^{c}$ & $7.8^{b}$ & $84^{\mathrm{a}}$ & $0.8^{c}$ & $66.8^{b}$ & $0.3^{\mathrm{d}}$ & $96.9^{c}$ \\
\hline & Max & 48.1 & 97 & 14.4 & 99.2 & 17.3 & 98.5 & 14.6 & 98.2 & 2.4 & 96.8 & 1.7 & 99.7 \\
\hline & Min & 28.84 & 93.5 & 4.8 & 96.8 & 1 & 70.8 & 0.7 & 75.4 & 0.1 & $\mathrm{n}$ & 0.03 & 81 \\
\hline \multirow{3}{*}{ Unplanted } & Aver & $150.2^{d}$ & $77.7^{\mathrm{f}}$ & $43.8^{\mathrm{f}}$ & $89.3^{\mathrm{e}}$ & $19.4^{\mathrm{e}}$ & $57.3^{d}$ & $13.5^{\mathrm{d}}$ & $63.3^{c}$ & $5.1^{\mathrm{b}}$ & $\mathrm{n}$ & $3.8^{\mathrm{e}}$ & $53.3^{d}$ \\
\hline & Max & 221.4 & 83.5 & 52.8 & 93.8 & 34.1 & 74.8 & 18.8 & 77.3 & 9 & 45 & 4.7 & 66.7 \\
\hline & Min & 110.4 & 65.5 & 25.9 & 87.2 & 12.5 & 24.4 & 8.6 & 49.1 & 0.9 & $\mathrm{n}$ & 2.8 & 45 \\
\hline
\end{tabular}
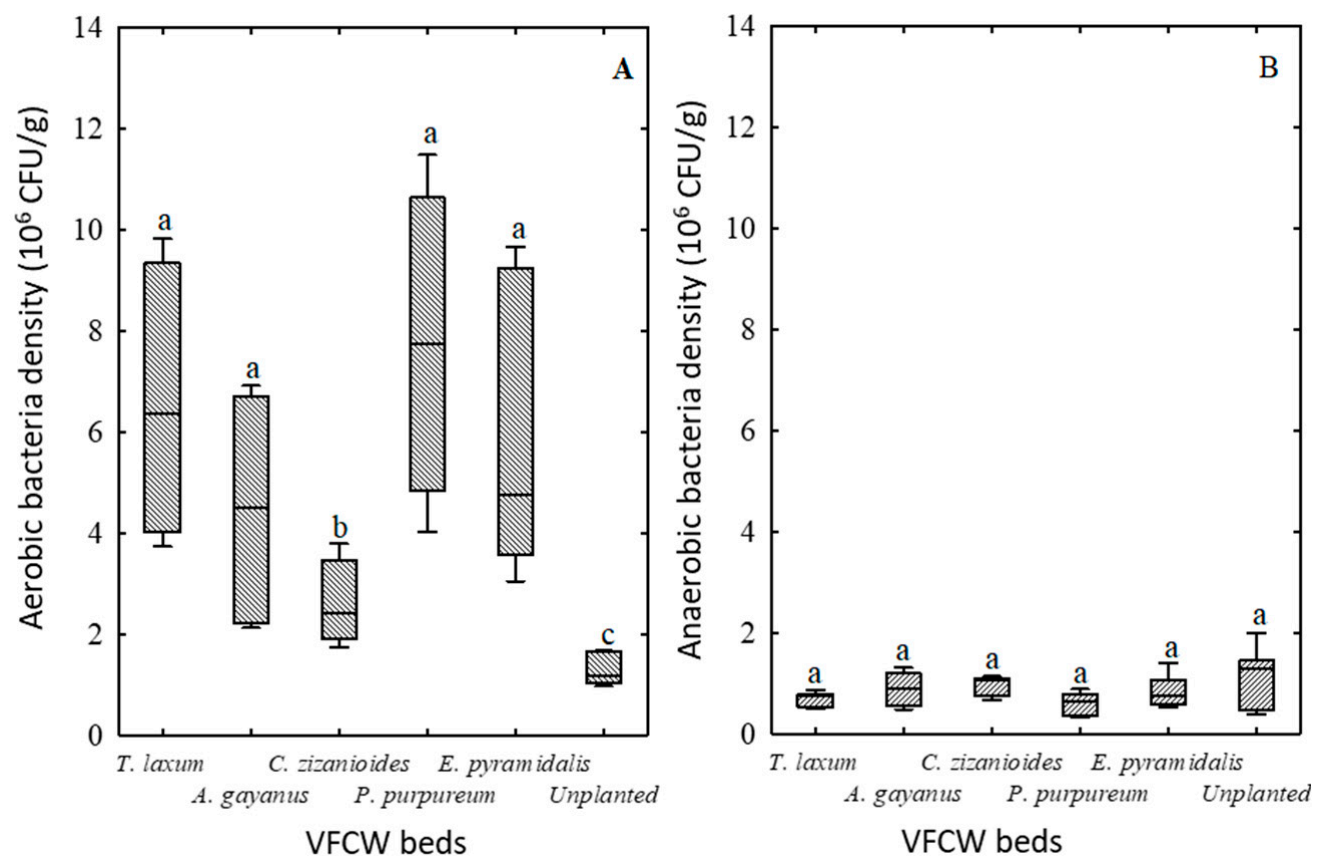

Figure 2. Variations of (A) aerobic, and (B) anaerobic bacteria densities in the pilot VFCWs substrate at the end the treatment trial. Box-plots bearing the same letter indicate no significant difference $(p>0.05)$.

No differences in anaerobic bacteria densities in the VFCWs substrate were observed between all beds (Mann-Whitney test: $p>0.05$ ), planted and unplanted (Figure 2B). The anaerobic bacteria densities generally ranged from 0.3 to $2 \times 10^{6} \mathrm{CFU} / \mathrm{g}$. The sequence of the median densities corresponded to the following order, showing a slightly higher 
number in the control bed (expressed in $10^{6} \mathrm{CFU} / \mathrm{g}$ ): P. purpureum $(0.7)<$ T. laxum $(0.8)<$ E. pyramidalis $(0.8)<$ A. gayanus $(0.9)<$ C. zizanioides $(1.1)<$ unplanted (1.3).

The total bacteria density was also assessed during the treatment period (Figure 3). It varied between 2.9 and $12.3 \times 10^{6} \mathrm{CFU} / \mathrm{g}$ in all beds, while the highest median density was found in the VFCW planted with P. purpureum and the lowest in the control bed. The decreasing order of total bacteria density was (expressed in $10^{6} \mathrm{CFU} / \mathrm{g}$ ): P. purpureum (8.4) $>$ T. laxum (7.1) $>$ E. pyramidalis (5.6) $>$ A. gayanus (5.4) $>$ C. zizanioides (3.5) $>$ unplanted (2.4). Finally, the total bacteria density of the planted VFCW beds was significantly higher than that obtained in the unplanted bed, whereas among the planted beds, the total bacteria density of the $C$. zizanioides bed was significantly lower than that of the others (MannWhitney test: $p<0.05)$.

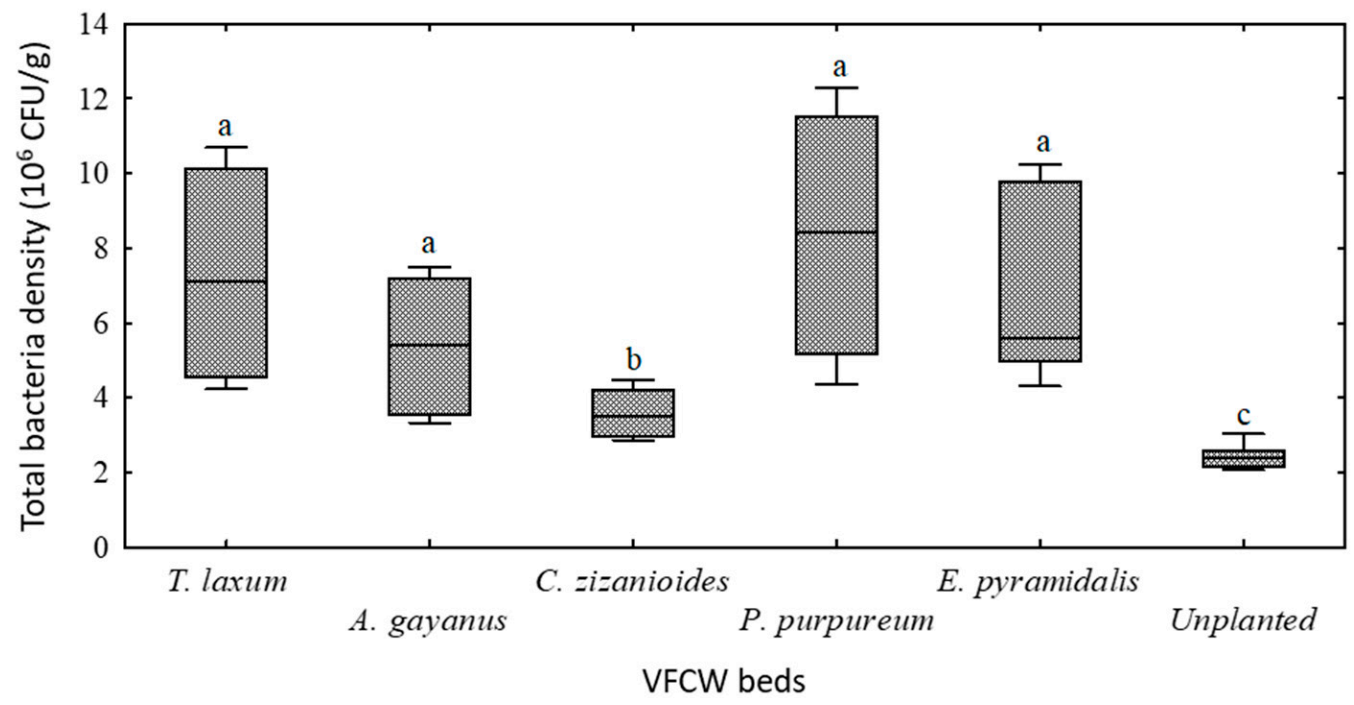

Figure 3. Variation of total bacteria density in the pilot VFCWs substrate at the end the treatment trial. Box-plots bearing the same letter indicate no significant difference $(p>0.05)$.

To better understand the bacteria evolution in the VFCWs substrate, the vertical profiles of aerobic, anaerobic and total bacteria densities in the different VFCW substrate layers were investigated. Figures 4-6 show the aerobic, anaerobic and total bacteria densities profiles, respectively. Overall, from the upper L1 [0-10 cm] to the bottom L6 [50-60 cm] layer of the pilot VFCWs, the number of aerobic bacteria decreased (from 17.4 to $0.1 \times 10^{6} \mathrm{CFU} / \mathrm{g}$; Figure 4), while that of anaerobic bacteria increased (from 0.1 to $2.1 \times 10^{6} \mathrm{CFU} / \mathrm{g}$; Figure 5). However, the total bacteria density decreased from the surface towards the bottom of the beds (from 17.4 to $1.5 \times 10^{6} \mathrm{CFU} / \mathrm{g}$; Figure 6). Aerobic bacteria density in the upper layers (L1 [0-10 cm] and L2 [10-20 cm]) was statistically higher than in the deeper layers (L5 [40-50 cm] and L6 [50-60 cm]) in the planted VFCW beds, while in the first three layers (L1 [0-10 cm], L2 [10-20 cm] and L3 [20-30 cm]), the bacteria densities in the planted beds were significantly higher than those in the unplanted bed $(p<0.05)$. Among the planted beds, the bacteria densities of the $C$. zizanioides bed was lower than those of the other beds, except for the A. gayanus bed in the L3 [20-30 cm] (Mann-Whitney test: $p<0.05$ ).

Unlike aerobic bacteria, the statistical analysis revealed that, in all VFCW beds, the anaerobic bacteria densities of the first two upper layers $(\mathrm{L} 1[0-10 \mathrm{~cm}]$ and L2 $[10-20 \mathrm{~cm}])$ were lower than those obtained in the bottom two layers (L5 [40-50 cm] and L6 [50-60 cm]; Mann-Whitney test: $p<0.05)$. Moreover, the anaerobic bacteria densities in the unplanted bed were not significantly different in the various consecutive layers (Figure 5). No differences were obtained between the planted VFCWs and the unplanted bed (Kruskal-Wallis test: $p>0.05$ ). 
L1 $[0-10 \mathrm{~cm}], \mathrm{L} 2[10-20 \mathrm{~cm}], \mathrm{L} 3[20-30 \mathrm{~cm}], \mathrm{L} 4[30-40 \mathrm{~cm}], \mathrm{L} 5[40-50 \mathrm{~cm}], \mathrm{L} 6[50-60 \mathrm{~cm}]$
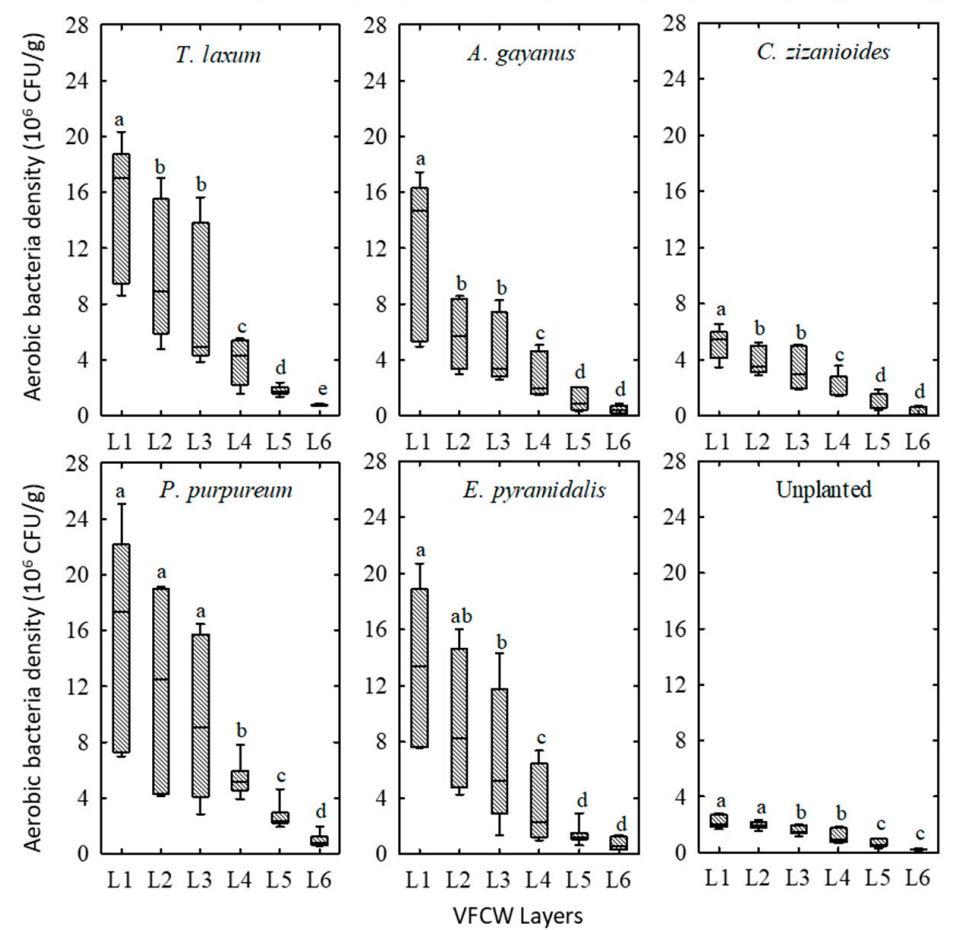

Figure 4. Vertical profile of aerobic bacteria density in the different substrate layers of the pilot VFCW beds from the upper to the bottom layers: L1 [0-10 cm], L2 [10-20 cm], L3 [20-30 cm], L4 [30-40 cm], L5 [40-50 cm], L6 [50-60 cm]. Box-plots bearing the same letter indicate no significant difference $(p>0.05)$.

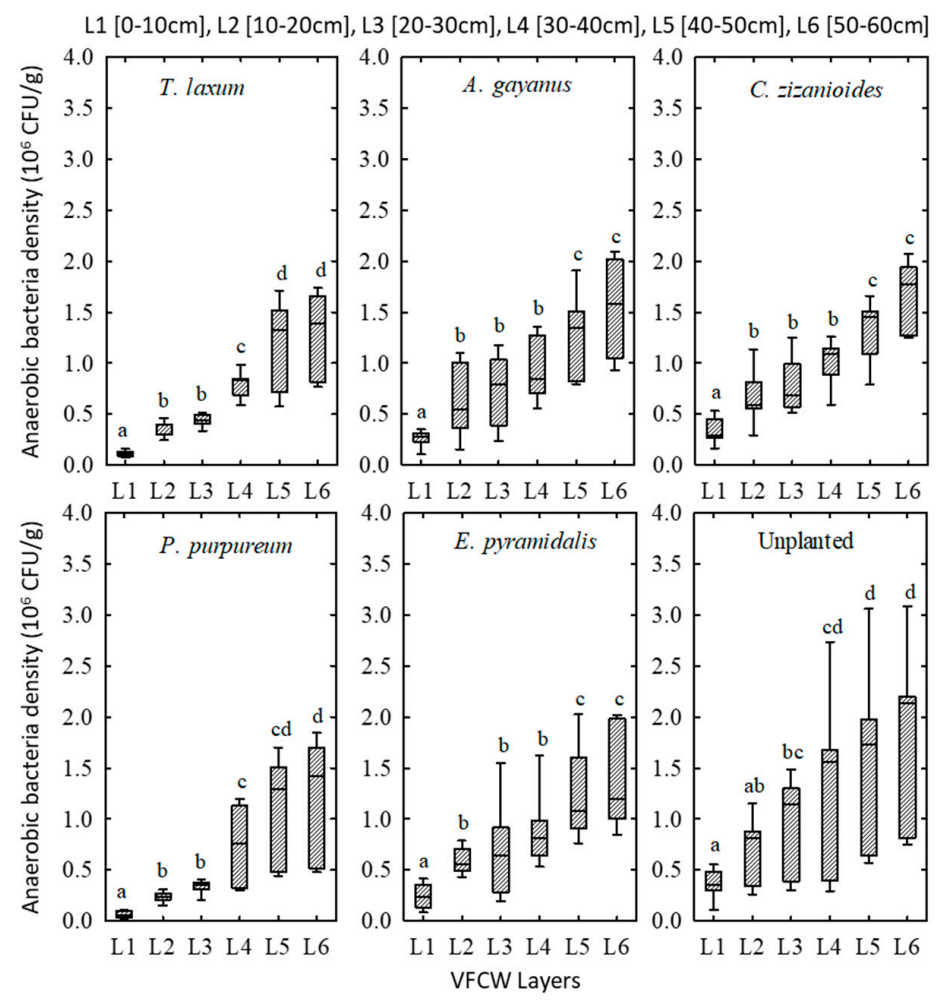

Figure 5. Vertical profile of anaerobic bacteria density in the different substrate layers of the pilot VFCW beds from the upper to the bottom layers: L1 [0-10 cm], L2 [10-20 cm], L3 [20-30 cm], L4 [30-40 cm], L5 [40-50 cm], L6 [50-60 cm]. Box-plots bearing the same letter indicate no significant difference $(p>0.05)$. 


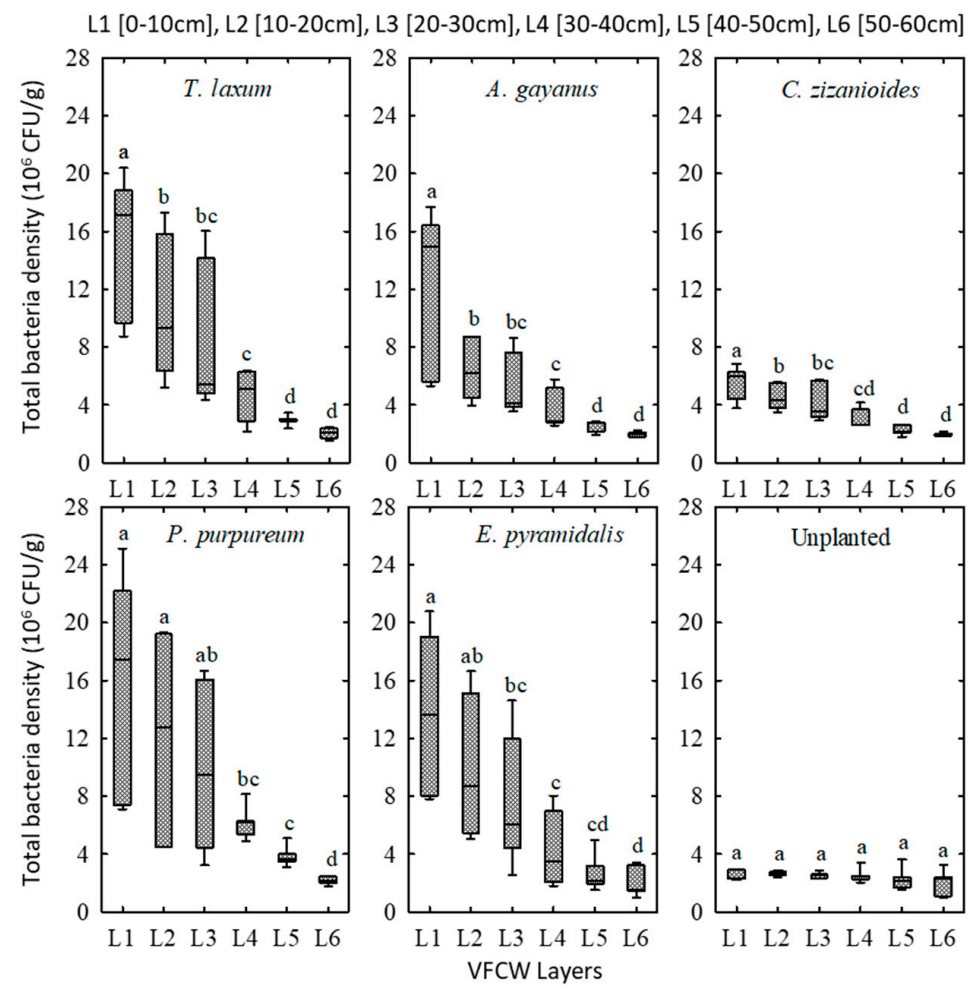

Figure 6. Vertical profile of total bacteria density in the different substrate layers of the pilot VFCW beds from the upper to the bottom layers: L1 [0-10 cm], L2 [10-20 cm], L3 [20-30 cm], L4 [30-40 cm], L5 [40-50 cm], L6 [50-60 cm]. Box-plots bearing the same letter indicate no significant difference $(p>0.05)$.

As for the aerobic bacteria, the total bacteria density in the beds was significantly higher in the upper (L1 [0-10 cm] and L2 [10-20 cm]) than in the deeper layers (L5 [40-50 cm] and L6 [50-60 cm]; Mann-Whitney test: $p<0.05$ ) (Figure 6). The total bacteria density in the VFCW bed planted with $C$. zizanioides was generally lower, whereas those of the other beds did not differ significantly. On the other hand, the total bacteria densities in the different planted beds were significantly higher than in the unplanted bed in the first two upper layers L1 $[0-10 \mathrm{~cm}]$ and L2 [10-20 cm]). The total bacteria densities were higher in the bed planted with P. purpureum, followed by T. laxum, E. pyramidalis, A. gayanus, C. zizanioides, and the unplanted bed.

\section{Discussion}

\subsection{Plant Growth Response}

The biomasses developed by E. pyramidalis, P. purpureum and T. laxum were significantly higher than those of $A$. gayanus and C. zizanioides, due to a favorable adaptation of these plants to the substrate provided. This result could be attributed to the quality of waters rich in nitrogen, phosphorus and various salts [3]. Other studies confirmed this assumption based on the nutrients provided [37,60], as is the case of the synthetic domestic wastewater used in this study, which provides the nutrients necessary for their growth. Among the five species studied, $P$. purpureum produced not only the most abundant biomass, but also had the largest stump diameter (Table 2). This result could be attributed to the specific ecological conditions, and an adaptation more favorable to the growth of this species. P. purpureum is known for its high biomass productivity and high yield potential, forming a deep, dense and fibrous root system that penetrates into the substrate [40]. Other studies with the same plant species also reported a large biomass production (i.e., $18-25 \mathrm{~kg} / \mathrm{m}^{2}$ ) in VFCWs receiving raw greywater [61] and domestic wastewater [62]. A higher biomass production is also found for P. purpureum compared to A. gayanus in another study [40]. T. laxum is also reported to have a high productivity and 
be insect- and disease-resistant, with thick but not greatly spreading rhizomes [63]. On the other hand, $C$. zizanioides is a tropical grass with robust but shorter rhizome whose density rapidly declines with depth $[45,64]$. E. pyramidalis showed a higher biomass production in this study compared to reported biomass in natural wetlands $\left(2 \mathrm{~kg} / \mathrm{m}^{2}\right)$, but a similar biomass $\left(5-8 \mathrm{~kg} / \mathrm{m}^{2}\right)$ with another study where this species was used in sludge treatment wetlands [65].

\subsection{VFCWs Performance}

The increase of effluent $\mathrm{pH}$ and DO compared to the inlet wastewater could be attributed to the biodegradation of organic matter and/or the metabolism of nutrient and its assimilation by plants, as well as to the interactions between the substrate media and the biofilm $[16,66]$. The absorption of nitrate ions through plant roots is countercurrent to a transport of hydroxide ions $\left(\mathrm{HO}^{-}\right)$from the plant to their outer environment or a co-transport of hydronium ions $\left(\mathrm{H}_{3} \mathrm{O}^{+}\right.$or $\left.\mathrm{H}^{+}\right)$within plant cells [67]. Hence, the release of the $\mathrm{OH}^{-}$ions in water during this process would also raise the $\mathrm{pH}$ of the VFCWs effluent. However, the higher $\mathrm{pH}$ of the unplanted bed compared to the planted beds could be due to the fact that the $\mathrm{CO}_{2}$ resulting from the biodegradation of organic matter acidifies the medium in the presence of water, which could release the calcium and magnesium hydrogen carbonate content in the synthetic wastewater, adsorbed partly in the substrates. Therefore, the mineralization of these compounds would increase the $\mathrm{pH}$ in the unplanted bed. Finally, the difference of $\mathrm{pH}$ observed between the planted beds is due to the physiological specificities of the plant species used. On the other hand, the increase of DO in the effluent would result mostly from the passive aeration of the inlet wastewater during its surface application to the VFCW beds and secondary from the oxygen released at the apex of the plant rootlets $[2,68]$.

The effluent volume in the VFCWs outlet was lower than the applied wastewater volume, regardless of the bed. This is related to evaporation and plant transpiration $[69,70]$, as well as the retention of a small water fraction in the bed substrate. Additionally, the difference in effluent volumes between the planted beds is due to the actual needs of each plant species, while the absence of plants in the unplanted bed would increase the rejection of water compared to the planted beds due to the absence of water loss via transpiration [6,7]. P. purpureum and T. laxum showed higher evapotranspiration rates (lower effluent volumes; Table 3), which should be attributed to the higher biomass production by these plant species and the respectively higher needs for water.

High removal efficiencies were obtained in the pilot VFCWs for organic matter, nitrogen and phosphorus pollutants. It is known that the VFCW design promotes aerobic removal processes as well as sedimentation and/or filtration mechanisms, which are the main removal mechanisms in CWs $[2,15,19,71]$. Organic matter removal (COD and $\mathrm{BOD}_{5}$ ) reached high levels in all 5 pilot planted units (90-99\%; Table 4). These removal rates are higher than the typical figures reported for single-stage VFCWs in the literature $[5,16,72]$. One reason for this is probably the warm climate that favors the biological oxidation of organic matter, as well as the aerobic conditions that typically dominate the VFCW bed [2]. However, other studies on VFCWs with the same plant species under similar climate reported lower removal rates, e.g., 62-90\% COD and $\mathrm{BOD}_{5}$ removal for P. purpureum [40,73], 92\% COD and $\mathrm{BOD}_{5}$ removal for E. pyramidalis [60], 58-80 COD removal for C. zizanioides [74-76], and 71-90\% COD and BOD 5 removal for A. gayanus $[40,42]$. These demonstrate the high effectiveness of the tested VFCW design in the removal of organic matter.

The unit with P. purpureum showed a higher removal of nitrogen compared to other studies reporting the efficiency of VFCWs planted with the same species, e.g., 50-70\% for TN [62], 44.3\% for TN [40], 62\% and 40-51.7\% for ammonia [73,77]. A higher removal of ammonia was also found with C. zizanioides compared to other VFCW systems (e.g., $67 \%$; [74]) and lower for TN (80\%; [74]), but operating at a longer HRT. A similar performance in nitrogen removal for the unit planted with E. pyramidalis is reported for a 
VFCW system treating leachate from a sludge treatment wetland [60]. Moreover, the TN removal of the unit with A. gayanus was almost double than that of another VFCW with the same plant species treating municipal wastewater (40.9\%; [40]). Generally, the tested units planted with tropical species had an ammonia and $\mathrm{TN}$ removal efficiency that is within the upper limits of the typically reported removal figures [34-95\% and 20-94\%, respectively] for VFCWs planted with common wetland species, such as Phragmites australis and Typha latifolia [2]. It is characteristic that removal rates above $85 \%$ are typically reported for two-stage VFCW systems (e.g., [72]) or for modified systems with effluent recirculation or wastewater step-feeding $[16,78]$. It should be pointed out that the main advantage of the present study is the warm tropical climate that promotes nitrification and results in high ammonia nitrogen removal and organic matter oxidation [2]. This is also reported for other VFCW studies implemented under warm climates [34,79].

On the other hand, as VFCWs are mostly aerobic systems, and considering the warm climate, enhanced nitrification usually results in increased effluent $\mathrm{NO}_{3}-\mathrm{N}[2,18]$, while $\mathrm{NO}_{3}-\mathrm{N}$ removal via denitrification requires an anaerobic environment $[2,15,16]$. The typical VFCW design employs an intermittent wastewater feed, thus leading to higher level oxygen availability for microbial metabolism during the biodegradation of various pollutants [2,14]. In addition, lagoon sand of uniform particle size used in this study as substrate favors sedimentation and/or filtration mechanisms as the wastewater drains vertically through the substrate layers of the bed [2,55]. Higher $\mathrm{NO}_{3}-\mathrm{N}$ in the VFCW effluent is also reported in other studies where the same species with the present study were used (e.g., E. pyramidalis [60]; P. purpureum [77]; C. zizanioides [74]). However, two plant species (P. purpureum and T. laxum) showed nitrate removal. This should probably be attributed to the higher biomass production of these species (Table 2) and the respectively higher nitrate uptake needs for growth as already elsewhere reported [62]. P. purpureum is reported to have a higher nitrogen uptake rate than other wetland plants [62]. A nitrate removal $(88 \%)$ in a VFCW planted with P. purpureum treating greywater has also been reported [61]. The $\mathrm{NO}_{3}-\mathrm{N}$ reduction in the effluent could possibly be explained by denitrification taking place in these units, considering that typically, at the bottom layers of VFCWs, anaerobic conditions dominate. Nevertheless, denitrification would also require an available carbon source for the denitrifying heterotrophic bacteria [16,66,72]. As these two units also showed the highest organic matter removal (Table 4) and the highest effluent DO (Table 3), it can be assumed that denitrification was limited, and plant uptake was probably the main nitrate removal mechanism for these species. In fact, various design modifications, such as partial saturation, increased bed depth, and effluent recirculation, have been proposed and tested to enhance the denitrification rate in VFCWs [16,71,77], though they increase the operational complexity and maintenance tasks.

It is also noteworthy that high removal rates were also found for TP (Table 4). These values are higher than those typically reported for VFCWs with other commonly used reed species [2], where media adsorption and plant uptake are the main mechanisms involved [2]. P. purpureum and T. laxum had the highest TP removal, indicating the higher assimilation of this nutrient by these plants [62]. Lower but still considerable removal rates are reported in other studies, i.e., $80 \%$ by $P$. purpureum [60], or even an increase in the effluent for a VFCW with C. zizanioides [76]. This high removal rate could be possibly attributed to the first growth period of the plants in the present study and the higher need for nutrients as well as to the fresh and unsaturated media, as has also been elsewhere reported $[2,18,71]$.

Moreover, the higher removal efficiencies in the planted beds than in the unplanted one indicate the stimulating effect of the plants on the degradation processes of organic matter $\left(\mathrm{COD}\right.$ and $\left.\mathrm{BOD}_{5}\right)$ and nutrients $\left(\mathrm{TN}, \mathrm{NH}_{4}-\mathrm{N}\right.$, and $\left.\mathrm{PO}_{4}-\mathrm{P}\right)$. Wetland plants promote aerobic processes by establishing an aerobic micro-environment along their roots that favors biofilm development $[2,21,69]$. Other removal pathways are also mediated by the secretion of root exudates [21,28,69], while plant uptake, precipitation or the dissolution, and the adsorption onto substrate grains would also contribute to further pollutants reduction 
in planted beds $[2,6,17,21]$. Several studies in the literature also report the improved performance of planted VFCWs over unplanted beds, indicating the positive role of plants presence in the VFCW system $[2,5-7,26]$.

Overall, the beds planted with $P$. purpureum and T. laxum were more efficient in pollutants removal than those with E. pyramidalis, A. gayanus and C. zizanioides, due to their higher plant biomass and the stumps developed (Table 2), as well as the secretion of different root exudates $[2,17,21]$.

\subsection{Bacteria Density in VFCWs}

The high aerobic bacteria density compared to anaerobic bacteria in all planted pilot VFCWs beds could be related to the favorable conditions for the proliferation of microbial communities created by the presence of vegetation. It is reported that plants improve the oxygenation of the rhizosphere by transferring atmospheric oxygen to the root zone $[2,3,80]$, which promotes the metabolism (i.e., secreting exudates) and growth of aerobic bacteria, thus favoring microbial activity in the substrate of the planted beds [81]. The CW macrophytes morphologically allow the transport of oxygen to the root system thanks to large cavities inside the stems and rhizomes [26,82].

In this study, the bacterial densities obtained (from 2.9 to $12.3 \times 10^{6} \mathrm{CFU} / \mathrm{g}$; Figure 6) were higher than those reported in other studies, e.g., $2.7 \times 10^{6} \mathrm{CFU} / \mathrm{g}$ [83], and less than those in others, e.g., $3.2 \times 10^{9} \mathrm{CFU} / \mathrm{g}$ in planted and $2.5 \times 10^{8} \mathrm{CFU} / \mathrm{g}$ in unplanted beds [84]. This difference could be explained by the different plant species used in the present study, the operation mode, and the CW type. For instance, the high bacterial density in the bed planted with P. purpureum compared to other planted beds would depend on its large aboveground biomass and stump diameter (Table 2) [85]. Furthermore, the trend of total bacterial density of the planted beds follows that of aerobic bacteria due to the low anaerobic bacterial density, thus indicating the predominance of aerobic conditions in the planted VFCWs compared to other CW types.

The investigation of the bacterial profile in the bed substrate showed that the aerobic bacteria number decreased from 17.4 to $0.1 \times 10^{6} \mathrm{CFU} / \mathrm{g}$ (Figure 4), while that of anaerobic bacteria increased from 0.1 to $2.1 \times 10^{6} \mathrm{CFU} / \mathrm{g}$ (Figure 5) from the upper L1 [0-10 cm] to the bottom layer L6 [50-60 cm] of the beds. In addition, the total bacterial number decreased with depth in all pilot beds (Figure 6). A change in bacterial diversity and a decline in densities with depth in VFCWs has also been elsewhere reported [86,87]. This result could be related to the gradual reduction of oxygen from the surface to the bottom. As the upper layers of the beds are better aerated $[14,71,84]$, the majority of the biological activity takes place within the first 10-20 cm [14,71,88], thus the development and growth of aerobic bacteria is favored than that of the anaerobic bacteria. On the other hand, in the bottom layers, the oxygen levels are relatively low, which would promote the growth of anaerobic bacteria. However, the trend of total bacteria indicated that aerobic bacteria dominate within the planted beds.

The significant differences in aerobic bacteria density between the first two layers and that of the bottom layer in the planted beds, and between the first three upper layers and the bottom layer in the unplanted bed, could be explained by the abundant roots and macroinvertebrates in the surface layers, whose activities would further aerate the upper layers of the VFCW $[89,90]$. Moreover, the difference of bacteria density observed between the planted beds should be attributed to the morphology of the different plant species. The sequence of aerobic bacteria densities in the pilot VFCWs (i.e., P. purpureum $>$ T. laxum $>$ E. pyramidalis $>$ A. gayanus $>$ C. zizanioides) is relatively similar to that of the produced plant biomasses and stumps diameter. The lowest aerobic bacteria density in the C. zizanioides is also related to the declining root density with depth for this species; it is reported that only $2.6 \%$ of root mass was found in layers deeper than the upper $20 \mathrm{~cm} \mathrm{[45],} \mathrm{while} \mathrm{this} \mathrm{species}$ is found to be negatively affected by anaerobic conditions that prevail in deeper layers [91]. In general, the higher plant biomasses (especially in the first layers) could have promoted a respectively high oxygenation of the beds (as indicated by respectively increased effluent 
DO levels), which would also explain the reverse sequence of anaerobic bacteria densities in the planted beds and the fewest aerobic bacteria in the unplanted bed.

\section{Conclusions}

Six pilot-scale VFCW beds planted with different local plant species were built and monitored for the treatment of domestic wastewater in west Africa. The removal of various pollutants and the bacterial densities were measured over a period of 7 months. This study demonstrated the high removal efficiency of the tested single-stage VFCW design. The presence of plants had a positive effect on the performance, through the increased bacterial density numbers and the enhanced removal efficiencies. The bacterial community in the VFCWs was dominated by aerobic bacteria, while smaller numbers of anaerobic bacteria were counted in the different VFCWs. Most of the beds could not effectively remove the effluent $\mathrm{NO}_{3}-\mathrm{N}$, as it is expected for this CW type, with the exception for the VFCWs planted with T. laxum and P. purpureum that demonstrated nitrate removal. From the upper to the bottom layers, the number of aerobic bacteria decreased, while that of anaerobic bacteria increased, implying the oxygen stratification along the depth (higher levels at the top, lower levels at the bottom). Overall, the bed planted with P. purpureum had the optimum performance, implying that VFCWs with this plant species can be used as a cost-effective nature-based solution for wastewater treatment in tropical climates.

Author Contributions: Conceptualization, F.M.Z., J.-M.P.O., L.C.; methodology, F.M.Z., J.-M.P.O.; software, F.M.Z., J.-M.P.O.; validation, F.M.Z., A.I.S.; formal analysis, F.M.Z., A.I.S.; investigation, F.M.Z., J.-M.P.O.; resources, F.M.Z., J.-M.P.O., A.I.S.; data curation, F.M.Z., J.-M.P.O., A.I.S.; writingoriginal draft preparation, J.-M.P.O., L.C.; writing-review and editing, F.M.Z., M.K., A.I.S.; visualization, F.M.Z., A.I.S.; supervision, M.K., L.C.; project administration, F.M.Z.; funding acquisition, J.-M.P.O., L.C. All authors have read and agreed to the published version of the manuscript.

Funding: This research received no external funding.

Data Availability Statement: For anyone interested, the data can be obtained by emailing the corresponding author.

Acknowledgments: This study has benefited from the technical support of the Laboratory of National of Testing, Quality, Metrology and Analysis of Cote d'Ivoire. The authors also deeply appreciate the valuable contributions of YEO Napari Elysée in obtaining the products of analysis and preparation of synthetic wastewater. We do not forget the late ASSI Yapo Jean from National Center of Floristic (NCF-Abidjan) and KOUADJA Gouagoua Séverin from National Center of Agronomic Research (NCAR-Bouaké), for their contribution in the selection of the tested plant species.

Conflicts of Interest: The authors declare no conflict of interest.

\section{References}

1. Vymazal, J. Constructed wetlands for wastewater treatment. Water 2010, 2, 530-549. [CrossRef]

2. Stefanakis, A.I.; Akratos, C.S.; Tsihrintzis, V.A. Vertical Flow Constructed Wetlands: Eco-Engineering Systems for Wastewater and Sludge Treatment, 1st ed.; Elsevier Publishing: Amsterdam, The Netherlands, 2014.

3. Dotro, G.; Langergraber, G.; Molle, P.; Nivala, J.; Puigagut, J.; Stein, O.R.; von Sperling, M. Treatment Wetlands, 1st ed.; IWA Publishing: London, UK, 2017.

4. Stefanakis, A.I.; Calheiros, C.S.C.; Nikolaou, I. Nature-based solutions as a tool in the new circular economic model for climate change adaptation. Circ. Econ. Sust. 2021, 1, 303-318. [CrossRef]

5. Stefanakis, A.I. The Role of Constructed wetlands as green infrastructure for sustainable urban water management. Sustainability 2019, 11, 6981. [CrossRef]

6. Gomes, A.C.; Silva, L.; Albuquerque, A.; Simões, R.; Stefanakis, A.I. Investigation of lab-scale horizontal subsurface flow constructed wetlands treating industrial cork boiling wastewater. Chemosphere 2018, 207, 430-439. [CrossRef] [PubMed]

7. Ramírez, S.; Torrealba, G.; Lameda-Cuicas, E.; Molina-Quintero, L.; Stefanakis, A.I.; Pire-Sierra, M.C. Investigation of pilot-scale Constructed Wetlands treating simulated pre-treated tannery wastewater under tropical climate. Chemosphere 2019, 234, 496-504. [CrossRef] [PubMed]

8. Gholipour, A.; Zahabi, H.; Stefanakis, A.I. A novel pilot and full-scale constructed wetland study for glass industry wastewater treatment. Chemosphere 2020, 247, 125966. [CrossRef] [PubMed] 
9. Stefanakis, A.I.; Prigent, S.; Breuer, R. Integrated produced water management in a desert oilfield using wetland technology and innovative reuse practices. In Constructed Wetlands for Industrial Wastewater Treatment, 1st ed.; Stefanakis, A.I., Ed.; John Wiley \& Sons Ltd.: Chichester, UK, 2018; pp. 25-42.

10. Buehler, D.; Antenen, N.; Frei, M.; Koller, C.; Rousseau, D.P.L.; Schoenborn, A.; Junge, R. Towards water and energy selfsufficiency: A closed-loop, solar-driven, low-tech laundry pilot facility (LaundReCycle) for the reuse of laundry wastewater. Circ. Econ. Sustain. 2021, 1, 1037-1051. [CrossRef]

11. Pineda-Martos, R.; Calheiros, C.S.C. Nature-Based Solutions in Cities-Contribution of the Portuguese National Association of Green Roofs to Urban Circularity. Circ. Econ. Sustain. 2021, 1, 1019-1035. [CrossRef]

12. Catalano, C.; Meslec, M.; Boileau, J.; Guarino, R.; Aurich, I.; Baumann, N.; Chartier, F.; Dalix, P.; Deramond, S.; Laube, P.; et al. Smart Sustainable Cities of the New Millennium: Towards Design for Nature. Circ. Econ. Sustain. 2021, 1, 1053-1086. [CrossRef]

13. Nikolaou, I.E.; Jones, N.; Stefanakis, A.I. Circular Economy and7 Sustainability: The Past, the Present and the Future Directions. Circ. Econ. Sustain. 2021, 1, 1-20. [CrossRef]

14. Stefanakis, A.I.; Nikolaou, I.E. Circular Economy and Sustainability, 1st ed.; Elsevier Publishing: Amsterdam, The Netherlands, 2021; Volume 2.

15. Nivala, J.; Wallace, S.; Headley, T. Oxygen transfer and consumption in subsurface flow treatment wetlands. Ecol. Eng. 2013, 61, 544-554. [CrossRef]

16. Al-Wahaibi, B.; Jafary, T.; Al-Mamun, A.; Baawain, M.S.; Aghbashio, M.; Tabatabaei, M.; Stefanakis, A.I. Operational modifications of a full-scale experimental vertical flow constructed wetland with effluent recirculation to optimize total nitrogen removal. J. Clean. Prod. 2021, 296, 126558. [CrossRef]

17. Vymazal, J. Removal of nutrients in various types of constructed wetlands. Sci. Total Environ. 2007, 380, 48-65. [CrossRef] [PubMed]

18. Stefanakis, A.I.; Tsihrintzis, V.A. Effects of loading, resting period, temperature, porous media, vegetation and aeration on performance of pilot-scale Vertical Flow Constructed Wetlands. Chem. Eng. J. 2012, 181-182, 416-430. [CrossRef]

19. Garcia, J.; Rousseau, D.P.L.; Morato, J.; Lesage, E.; Matamoros, V.; Bayona, J.M. Contaminant removal process in subsurface-flow constructed wetlands: A review. Crit. Rev. Environ. Sci. Technol. 2010, 40, 561-661. [CrossRef]

20. Choudhary, A.K.; Kumar, S.; Sharma, K. Constructed wetlands: An approach for waste-water treatment. Elixir Pollut. 2011, 37, 666-3672.

21. Stefanakis, A.I.; Akratos, C.S. Removal of pathogenic bacteria in constructed wetlands: Mechanisms and efficiency. In Phytoremediation, 1st ed.; Ansari, A., Gill, S., Gill, R., Lanza, G., Newman, L., Eds.; Springer: Cham, Switzerland, 2016; Volume 4, pp. 327-346.

22. Stottmeister, U.; Wiener, A.; Kuschk, P.; Kappelmeyer, U.; Kästner, M.; Bederski, O.; Müller, R.A.; Moormann, H. Effects of plants and microorganisms in constructed wetlands for wastewater treatment. Biotechnol. Adv. 2003, 22, 93-117. [CrossRef]

23. Richardson, A.E.; Simpson, R.J. Soil microorganisms mediating phosphorus availability. Plant Physiol. 2011, 156, 989-996. [CrossRef] [PubMed]

24. Wu, H.; Zhang, J.; Li, P.; Zhang, J.; Xie, H.; Zhang, B. Nutrient removal in constructed microcosm wetlands for treating polluted river water in northern China. Ecol. Eng. 2011, 37, 560-568. [CrossRef]

25. Wu, H.; Zhang, J.; Wei, R.; Liang, S.; Li, C.; Xie, H. Nitrogen transformations and balance in constructed wetlands for slightly polluted river water treatment using different macrophytes. Environ. Sci. Pollut. Res. 2013, 20, 443-451. [CrossRef] [PubMed]

26. Schultze-Nobre, L.; Wiessner, A.; Bartsch, C.; Paschke, H.; Stefanakis, A.I.; Aylward, L.A.; Kuschk, P. Removal of dimethylphenols and ammonium in laboratory-scale horizontal subsurface flow Constructed Wetlands. Eng. Life Sci. 2017, 17, 1224-1233. [CrossRef]

27. Truu, M.; Juhanson, J.; Truu, J. Microbial biomass, activity and community composition in constructed wetlands. Sci. Total Environ. 2009, 407, 3958-3971. [CrossRef]

28. Weber, K.P.; Gagnon, V. Microbiology in treatment wetlands. Sustain. Sanit. Pract. 2014, 18, 25-30.

29. Wang, Q.; Xie, H.; Ngo, H.H.; Guo, W.; Zhang, J.; Liu, C.; Liang, S.; Hu, Z.; Yang, Z.; Zhao, C. Microbial abundance and community in subsurface flow constructed wetland microcosms: Role of plant presence. Environ. Sci. Pollut. Res. 2016, 23, 4036-4045. [CrossRef] [PubMed]

30. Puigagut, J.; Salvadó, H.; García, D.; Granes, F.; García, J. Comparison of microfauna communities in full scale subsurface flow constructed wetlands used as secondary and tertiary treatment. Water Res. 2007, 41, 1645-1652. [CrossRef] [PubMed]

31. Zhang, D.Q.; Jinadasa, K.B.S.N.; Gersberg, R.M.; Liu, Y.; Ng, W.J.; Tan, S.K. Application of constructed wetlands for wastewater treatment in developing countries-A review of recent developments (2000-2013). J. Environ. Manag. 2014, 141, 116-131. [CrossRef]

32. Varma, M.; Gupta, A.K.; Ghosal, P.S.; Majumder, A. A review on performance of constructed wetlands in tropical and cold climate: Insights of mechanism, role of influencing factors, and system modification in low temperature. Sci. Total Environ. 2021, 755, 142540. [CrossRef] [PubMed]

33. Haddis, A.; Van der Bruggen, B.; Smets, I. Constructed wetlands as nature-based solutions in removing organic pollutants from wastewater under irregular flow conditions in a tropical climate. Ecohydrol. Hydrobiol. 2020, 20, 38-47. [CrossRef]

34. Stefanakis, A.I. Constructed wetlands for sustainable wastewater treatment in hot and arid climates: Opportunities, challenges and case studies in the Middle East. Water 2020, 12, 1665. [CrossRef] 
35. Coulibaly, L.; Kouakou, J.; Savané, I.; Gourène, G. Domestic wastewater treatment with a vertical completely drained pilot scale constructed wetland planted with Amaranthus hybridus. Afr. J. Biotechnol. 2008, 7, 2656-2664.

36. Coulibaly, L.; Savané, I.; Gourene, G. Domestic wastewater treatment with a vertical completely drained pilot scale constructed wetland planted with Corchorus oliterius. Afr. J. Agric. Res. 2008, 3, 587-596.

37. Ouattara, P.J.-M.; Coulibaly, L.; Manizan, P.; Gourène, G. Traitement des eaux résiduaires urbaines par un marais artificiel à drainage vertical planté avec Panicum maximum sous climat tropical. Eur. J. Sci. Res. 2008, 23, 25-40.

38. Rodgers, M.; Lambe, A.; Xiao, L. Carbon and nitrogen removal using a novel horizontal flow biofilm system. Process Biochem. 2006, 41, 2270-2275. [CrossRef]

39. Healy, M.G.; Burke, P.; Rodgers, M. The use of laboratory sand, soil and crushed-glass filter columns for polishing domesticstrength synthetic wastewater that has undergone secondary treatment. J. Environ. Sci. Health 2010, 45, 1635-1641. [CrossRef] [PubMed]

40. Pillai, J.S.; Nair, A.N.B. Performance of vertical flow constructed wetlands planted with indigenous species for decentralized wastewater treatment and biomass production in Kerala, India. Nat. Environ. Pollut. Technol. 2021, 20, 541-550. [CrossRef]

41. Flores, T.A.; Setterfield, S.A.; Douglas, M.M. Seedling recruitment of the exotic grass Andropogon gayanus (Poaceae) in northern Australia. Aust. J. Bot. 2005, 53, 243-249. [CrossRef]

42. Joceline, S.B.; Kone, M.; Yacouba, O.; Arsene, Y.J. Planted sludge drying beds in treatment of faecal sludge from Ouagadougou: Case of two local plant species. J. Water Resour. Prot. 2016, 8, 697-705. [CrossRef]

43. Milani, M.; Marzo, A.; Toscano, A.; Consoli, S.; Cirelli, G.L.; Ventura, D.; Barbagallo, S. Evapotranspiration from horizontal subsurface flow constructed wetlands planted with different perennial plant species. Water 2019, 11, 2159. [CrossRef]

44. Panja, S.; Sarkar, D.; Zhang, Z.; Datta, R. Removal of antibiotics and nutrients by vetiver grass (Chrysopogon zizanioides) from a plug flow reactor based constructed wetland model. Toxics 2021, 9, 84. [CrossRef]

45. Barbera, A.C.; Borin, M.; Cirelli, G.L.; Toscano, A.L.; Maucieri, C. Comparison of carbon balance in Mediterranean pilot constructed wetlands vegetated with different C4 plant species. Environ. Sci. Pollut. Res. 2015, 22, 2372-2383. [CrossRef]

46. Fasani, E.; DalCorso, G.; Zerminiani, A.; Ferrarese, A.; Campostrini, P.; Furini, A. Phytoremediatory efficiency of Chrysopogon zizanioides in the treatment of landfill leachate: A case study. Environ. Sci. Pollut. Res. 2019, 26, 10057-10069. [CrossRef] [PubMed]

47. Ngoutane Pare, M.N.; Koné, D.; Kengne, I.M.; Dongo, K.; Akoa, A. Nutritional potential of Echinochloa pyramidalis (Lam.) Hitchc. \& chase, a forage plant used in constructed wetlands treatment of faecal sludge and wastewater. Afr. J. Agric. Res. 2011, $6,4397-4408$.

48. Kengne, I.M.; Kengne, E.S.; Akoa, A.; Bemmo, N.; Dodane, P.-H.; Koné, D. Vertical-flow constructed wetlands as an emerging solution for faecal sludge dewatering in developing countries. J. Water Sanit. Hyg. Dev. 2011, 1, 13-19. [CrossRef]

49. Perera, A.N.F.; Perera, E.R.K. Nutritive value and ensiling characteristics of Guatemala grass harvested at different stages of maturity. J. Nat. Sci. Found. Sri Lanka 1994, 22, 245-251. [CrossRef]

50. Sirianuntapiboon, S.; Jitvimolnimit, S. Effect of plantation pattern on the efficiency of subsurface flow constructed wetland (sfcw) for sewage treatment. Afr. J. Agric. Res. 2007, 2, 447-454.

51. ISO. International Standardization Organization (ISO) 6222: Water Quality—Enumeration of Culturable Micro-Organisms-Colony Count by Inoculation in a Nutrient Agar Culture Medium, 2nd ed.; ISO: Geneve, Switzerland, 1999.

52. ISO. International Standardization Organization (ISO) 10523: Water Quality-Determination of pH-Analytical Measurement, 2nd ed.; ISO: Geneve, Switzerland, 2008.

53. ISO. International Standardization Organization (ISO) 5814: Water Quality-Determination of Dissolved Oxygen-Electrochemical Probe Method, 3rd ed.; ISO: Geneve, Switzerland, 2012.

54. ISO. International Standardization Organization (ISO) 6060/2: Water Quality-Determination of Chemical Oxygen Demand-Potassium Dichromate Method, 2nd ed.; ISO: Geneve, Switzerland, 1989.

55. ISO. International Standardization Organization (ISO) 5815: Water Quality—Determination of Biochemical Oxygen Demand after $n$ Days (BODn)_Part 1: Dilution and Seeding Method with Allylthiourea Addition, 1st ed.; ISO: Geneve, Switzerland, 2003.

56. ISO. International Standardization Organization (ISO) 5663: Water Quality-Determination of Kjedahl Nitrogen-Method after Mineralization with Selenium, 1st ed.; ISO: Geneve, Switzerland, 1984.

57. ISO. International Standardization Organization (ISO) 7150/1: Water Quality-Determination of Ammonium-Part 1 Manual Spectrometric Method, 1st ed.; ISO: Geneve, Switzerland, 1984.

58. ISO. International Standardization Organization (ISO) 7890/3: Water Quality-Determination of Nitrate-Part 3: Spectrometric Method Using Sulfosalicylic Acid, 1st ed.; ISO: Geneve, Switzerland, 1988.

59. ISO. International Standardization Organization (ISO) 6878: Water Quality-Determination of Phosphorus-Ammonium Molybdate Spectrometric Method, 2nd ed.; ISO: Geneve, Switzerland, 2004.

60. Kengne, E.S.; Kengne, I.M.; Nzouebet, W.A.L.; Akoa, A.; Hung, N.V.; Strande, L. Performance of vertical flow constructed wetlands for faecal sludge drying bed leachate: Effect of hydraulic loading. Ecol. Eng. 2014, 71, 384-393. [CrossRef]

61. Pillai, J.S.; Vijayan, N. wastewater treatment: An ecological sanitation approach in a constructed wetland. International Journal of Innovative. Int. J. Innov. Res. Sci. Eng. Technol. 2013, 2, 5193-5204.

62. Xu, Q.; Hunag, Z.; Wang, X.; Cui, L. Pennisetum sinese Roxb and Pennisetum purpureum Schum. as vertical-flow constructed wetland vegetation for removal of $\mathrm{N}$ and $\mathrm{P}$ from domestic sewage. Ecol. Eng. 2015, 83, 120-124. [CrossRef] 
63. Gray, J.R. The Genus Tripsacum L. (Gramineae): Taxonomy and Chemosystematics. Ph.D. Thesis, University of Illinois at Urbana-Champaign, Urbana, IL, USA, 1974.

64. Almeida, A.; Carvalho, F.; Imaginário, M.J.; Castanheira, I.; Prazeres, A.R.; Ribeiro, C. Nitrate removal in vertical flow constructed wetland planted with Vetiveria zizanioides: Effect of hydraulic load. Ecol. Eng. 2017, 99, 535-542. [CrossRef]

65. Kengne, I.M.; Akoa, A.; Soh, E.K.; Tsama, V.; Ngoutane, M.M.; Dodane, P.H.; Kone, D. Effects of faecal sludge application on growth characteristics and chemical composition of Echinochloa pyramidalis (Lam.) Hitch. and Chase and Cyperus papyrus L. Ecol. Eng. 2008, 34, 233-242. [CrossRef]

66. Koné, M.; Zongo, I.; Bonou, L.; Koulidiati, J.; Joly, P.; Bouvet, Y.; Sodre, S. Traitement d'eaux résiduaires urbaines par filtres plantés à flux vertical sous climat Soudano-Sahélien. Int. J. Biol. Chem. Sci. 2011, 5, 217-231. [CrossRef]

67. Wegner, L.H. Cotransport of water and solutes in plant membranes: The molecular basis, and physiological functions. AIMS Biophys. 2017, 4, 192-209. [CrossRef]

68. Pérez, M.M.; Hernández, J.M.; Bossens, J.; Jiménez, T.; Rosa, E.; Tack, F. Vertical flow constructed wetlands: Kinetics of nutrient and organic matter removal. Water Sci. Technol. 2014, 70, 76-81. [CrossRef]

69. Kadlec, R.; Wallace, S. Treatment Wetlands, 2nd ed.; CRC Press, Taylor \& Francis, Group: Boca Raton, FL, USA, 2009.

70. Gomes, A.C.; Silva, L.; Albuquerque, A.; Simões, R.; Stefanakis, A.I. Treatment of cork boiling wastewater using a horizontal subsurface flow constructed wetland combined with ozonation. Chemosphere 2020, 260, 127598. [CrossRef]

71. Gholipour, A.; Stefanakis, A.I. A full-scale anaerobic baffled reactor and hybrid constructed wetland for university dormitory wastewater treatment and reuse in an arid and warm climate. Ecol. Eng. 2021, 170, 106360. [CrossRef]

72. Morvannou, A.; Forquet, N.; Michel, S.; Troesch, S.; Molle, P. Treatment performances of French constructed wetlands: Results from a database collected over the last 30 years. Water Sci. Technol. 2015, 71, 1333-1339. [CrossRef]

73. Ujang, F.A.; Roslan, A.M.; Osman, N.A.; Norman, A.; Idris, J.; Farid, M.A.A.; Halmi, M.I.E.; Gozan, M.; Hassan, M.A. Removal behaviour of residual pollutants from biologically treated palm oil mill effluent by Pennisetum purpureum in constructed wetland. Sci. Rep. 2021, 11, 18257. [CrossRef] [PubMed]

74. Wang, X.; Han, B.P.; Shi, Y.Z.; Pang, Z.Q. Advanced wastewater treatment by integrated vertical flow constructed wetland with vetiveria zizanioides in north China. Procedia Earth Planet Sci. 2009, 1, 1258-1262. [CrossRef]

75. Almeida, A.; Ribeiro, C.; Carvalho, F.; Durao, A.; Bugajski, P.; Kurek, K.; Pochwatka, P.; Jóźwiakowski, K. Phytoremediation potential of Vetiveria zizanioides and Oryza sativa to nitrate and organic substance removal in vertical flow constructed wetland systems. Ecol. Eng. 2019, 138, 19-27. [CrossRef]

76. Badejo, A.A.; Omole, D.O.; Ndambuki, J.M. Municipal wastewater management using Vetiveria zizanioides planted in vertical flow constructed wetland. Appl. Water Sci. 2018, 8, 110. [CrossRef]

77. Xu, Q.; Wang, P.; Zhang, F.; Wang, L. The influence of the outlet position and substrate on the nitrogen purification of vertical flow constructed wetlands. IOP Conf. Ser. Earth Environ. Sci. 2020, 601, 012048. [CrossRef]

78. Nivala, J.; Abdallat, G.; Aubron, T.; Al-Zreiqat, I.; Abbassi, B.; Wu, G.-M.; van Afferden, M.; Mueller, R.A. Vertical flow constructed wetlands for decentralized wastewater treatment in Jordan: Optimization of total nitrogen removal. Sci. Total Environ. 2019, 671, 495-504. [CrossRef] [PubMed]

79. Molle, P.; Latune, R.L.; Riegel, G.; Esser, D.; Mangeot, L. French vertical-flow constructed wetland design: Adaptations for tropical climates. Water Sci. Technol. 2015, 71, 1516-1523. [CrossRef]

80. Fan, J.; Liang, S.; Zhang, B.; Zhang, J. Enhanced organics and nitrogen removal in batch-operated vertical flow constructed wetlands by combination of intermittent aeration and step feeding strategy. Environ. Sci. Pollut. Res. 2013, 20, $2448-2455$. [CrossRef] [PubMed]

81. Wang, Q.; Hu, Y.; Xie, H.; Yang, Z. Constructed Wetlands: A review on the role of radial oxygen loss in the rhizosphere by macrophytes. Water 2018, 10, 678. [CrossRef]

82. Zhai, X.; Piwpuan, N.; Arias, C.A.; Headley, T.; Brix, H. Can root exudates from emergent wetland plants fuel denitrification in subsurface flow constructed wetland systems? Ecol. Eng. 2013, 61, 555-563. [CrossRef]

83. Hatano, K.; Trettin, C.C.; House, C.H.; Wollum, A.G., II. Microbial populations and decomposition activity in three subsurface flow constructed wetlands. In Constructed Wetlands for Water Quality Improvement, 1st ed.; Moshiri, G.A., Ed.; Lewis Publishers: London, UK, 1993; pp. 541-547.

84. Münch, C.; Kuschk, P.; Roske, I. Root stimulated nitrogen removal: Only a local effect or important for water treatment? Water Sci. Technol. 2005, 51, 85-192. [CrossRef]

85. Gagnon, V.; Chazarenc, F.; Comeau, Y.; Brisson, J. Influence of macrophyte species on microbial density and activity in constructed wetlands. Water Sci. Technol. 2007, 56, 249-254. [CrossRef] [PubMed]

86. Zhou, Q.; He, F.; Liping, Z.; Wang, Y.; Wu, Z. Characteristics of the microbial communities in the integrated vertical-flow constructed wetlands. J. Environ. Sci. 2009, 21, 1261-1267. [CrossRef]

87. Hua, G.; Cheng, Y.; Kong, J.; Li, M.; Zhao, Z. High-throughput sequencing analysis of bacterial community spatiotemporal distribution in response to clogging in vertical flow constructed wetlands. Bioresour. Technol. 2018, 248B, 104-112. [CrossRef] [PubMed]

88. Molle, P. French vertical flow constructed wetlands: A need of a better understanding of the role of the deposit layer. Water Sci. Technol. 2014, 69, 106-112. [CrossRef] [PubMed] 
89. Ouattara, P.J.-M.; Coulibaly, L.; Tiho, S.; Gourene, G. Comparison of macrofauna communities in sediments of the beds of vertical flow constructed wetlands planted with Panicum maximum (Jacq.) treating domestic wastewater. Ecol. Eng. 2009, 35, $1237-1242$. [CrossRef]

90. Ouattara, P.J.-M.; Coulibaly, L.; Tiho, S.; Ouattara, A.; Gourene, G. Panicum maximum (Jacq.) density effect upon macrofauna structure in sediments of pilot-scale vertical flow constructed wetlands treating domestic wastewater. Ecol. Eng. 2011, 37, 217-223. [CrossRef]

91. Darajeh, N.; Idris, A.; Masoumi, H.R.F.; Nourani, A.; Truong, P.; Sairi, N.A. Modeling BOD and COD removal from palm oil mill secondary effluent in floating wetland by Chrysopogon zizanioides (L.) using response surface methodology. J. Environ. Manag. 2016, 181, 343-352. [CrossRef] [PubMed] 